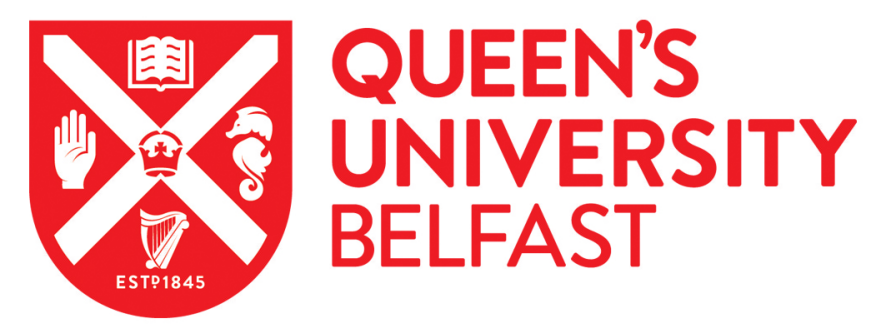

\title{
Development of amphiphilic block copolymers as silica optical fiber overlayers for BSA protein detection
}

Petropoulou, A., Gibson, T. J., Themistou, E., Pispas, S., \& Riziotis, C. (2018). Development of amphiphilic block copolymers as silica optical fiber overlayers for BSA protein detection. Materials Chemistry and Physics, 216, 421-428. https://doi.org/10.1016/j.matchemphys.2018.06.027

Published in:

Materials Chemistry and Physics

Document Version:

Peer reviewed version

Queen's University Belfast - Research Portal:

Link to publication record in Queen's University Belfast Research Portal

Publisher rights

(C) 2018 Elsevier.

This manuscript is distributed under a Creative Commons Attribution-NonCommercial-NoDerivs License

(https://creativecommons.org/licenses/by-nc-nd/4.0/), which permits distribution and reproduction for non-commercial purposes, provided the author and source are cited.

\section{General rights}

Copyright for the publications made accessible via the Queen's University Belfast Research Portal is retained by the author(s) and / or other copyright owners and it is a condition of accessing these publications that users recognise and abide by the legal requirements associated with these rights.

Take down policy

The Research Portal is Queen's institutional repository that provides access to Queen's research output. Every effort has been made to ensure that content in the Research Portal does not infringe any person's rights, or applicable UK laws. If you discover content in the Research Portal that you believe breaches copyright or violates any law, please contact openaccess@qub.ac.uk. 


\section{Accepted Manuscript}

Development of amphiphilic block copolymers as silica optical fiber overlayers for BSA protein detection

Afroditi Petropoulou, Thomas J. Gibson, Efrosyni Themistou, Stergios Pispas,

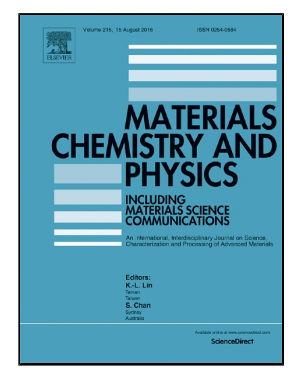

Christos Riziotis

PII:

S0254-0584(18)30526-1

DOI:

10.1016/j.matchemphys.2018.06.027

Reference:

MAC 20727

To appear in:

Materials Chemistry and Physics

Received Date:

08 January 2018

Accepted Date:

10 June 2018

Please cite this article as: Afroditi Petropoulou, Thomas J. Gibson, Efrosyni Themistou, Stergios Pispas, Christos Riziotis, Development of amphiphilic block copolymers as silica optical fiber overlayers for BSA protein detection, Materials Chemistry and Physics (2018), doi: 10.1016/j. matchemphys.2018.06.027

This is a PDF file of an unedited manuscript that has been accepted for publication. As a service to our customers we are providing this early version of the manuscript. The manuscript will undergo copyediting, typesetting, and review of the resulting proof before it is published in its final form. Please note that during the production process errors may be discovered which could affect the content, and all legal disclaimers that apply to the journal pertain. 


\title{
Development of amphiphilic block copolymers as silica optical fiber overlayers for BSA protein detection
}

\author{
Afroditi Petropoulou, ${ }^{a, c}$, Thomas J. Gibson ${ }^{b}$, Efrosyni Themistou ${ }^{b}$, Stergios Pispas ${ }^{a}$, Christos Riziotis*,a \\ aTheoretical and Physical Chemistry Institute, National Hellenic Research Foundation, 48 Vassileos \\ Constantinou Avenue, 11635 Athens, Greece \\ ${ }^{b}$ School of Chemistry and Chemical Engineering, Queen's University Belfast, Belfast BT9 5AG, U.K. \\ 'Department of Informatics and Telecommunications, University of Peloponnese, Tripolis 22100, Greece \\ *Corresponding Author: Ch. Riziotis (riziotis@eie.gr)
}

\begin{abstract}
Novel amphiphilic block copolymers having both hydrophobic poly(methyl methacrylate) (PMMA) and hydrophilic poly[2-(dimethylamino)ethyl methacrylate] (PDMAEMA) blocks have been designed and synthesized for efficient protein detection in photonic-based sensing. Both the cationic $\mathrm{PMMA}_{117}-b$ PDMAEMA $_{16}$ and the cationic vinyl-sulfone functionalized $\mathrm{PMMA}_{117}-b-\mathrm{P}\left(\mathrm{DMAEMA}_{17}-\mathrm{VSTEMA}_{2}\right)$ block copolymers were synthesized from a water insoluble hydrophobic PMMA block, which facilitated the formation of stable overlayers on the silica optical fibers surface. The well-defined structure of the copolymers was confirmed by gel permeation chromatography (GPC). The presence of the cationic PDMAEMA block and the vinyl-sulfone double bonds led to reversible electrostatic binding of negatively charged proteins like bovine serum albumin (BSA) and non-reversible chemical binding by thiol-ene reactions with cysteine in proteins, respectively. The sensing properties of these materials were assessed and confirmed by ATR-FTIR analysis and by the characterization of fabricated sensing heads on silica optical fibers functionalized with suitably deposited overlayers. The sensing assessment revealed the requirements for deposited overlayer characteristics towards proteins' detection sensitivity and selectivity enhancement.
\end{abstract}

Keywords: proteins, polymers, block copolymers, optical fibers, photonic sensors, biosensing

\section{Introduction}

Proteins are a class of major biomolecules that play a crucial role in many areas such as the food industry, biotechnology and medicine. The need for reliable sensing and quantitative control of proteins has fuelled the development of several protein detection methods over the past decades that can provide both sensitivity and selectivity. Due to their monitoring importance a number of different, sophisticated and quite diverse approaches for protein detection have been developed. Aptasensors based on electrochemical interactions have been demonstrated with a high degree of selectivity in the coexistence of other proteins $[1,2]$. Furthermore complex techniques like electrochemical impedance spectroscopy based on suitable aptamers as molecular recognition element [3], or monitoring of Atomic Force Microscopy -AFM cantilevers' deflection and bending under electrostatic interactions [4], and Bulk Acoustic Wave (BAW) viscosity sensor [5] were used as protein detection methods. Although some of the aforementioned techniques achieve a high degree of sensitivity, their implementation and use are rather laborious, expensive and require complex interrogation instrumentation setups leading to time consuming processes that in many cases are inapplicable in practical applications. 
Further to the above, other optical-based and complex spectroscopic techniques have been employed for protein detection, like surface plasmon resonance (SPR) [6 - 10] for label-free detection, fluorescence detection which enables the identification of specific protein modifications [11] and sensitive surface-enhanced Raman scattering (SERS)-based biosensors for label-free macromolecule detections [12].

Photonic biosensors is also an emerging class of protein sensors as they offer various advantages such as immunity to electromagnetic interference, reliability, fast response, large dynamic range and ability to operate in harsh environmental conditions. Various photonic structures have been proposed for biological sensing including optofluidics [13 - 15], photonic crystals [16], Bragg grating based optical sensing [17] and photonic resonant optical microcavities [18 - 20]. Although their use or combination in complex photonic circuits could provide high sensitivity and functionality towards miniaturized devices for point of care applications, their development is still quite complex requiring expensive instrumentation and complex interrogation systems. The associated increased cost and operational complexity has limited greatly their applicability in real applications.

The sensing scheme complexity can be balanced by integrating new sensitive materials that can offer increased sensitivity in detection platforms with low cost instrumentation. This direction has led to the design and synthesis of functional materials that offer selectivity by efficient adsorption of specific molecules, enhancing the sensitivity $[21,22]$. The combination of new sensing materials and large core optical fibers provide additionally flexibility, mechanical robustness, high degree of miniaturization, as well as long interaction length while their operational characteristics can allow the efficient integration of sensing heads in monitoring units. The deposition of such materials to an unclad segment of multimode polymer $[23,24]$ or silica $[25,26]$ optical fiber, which can act as both the sensing and signal collection element, can result to the development of low cost and low complexity sensors. The selection also of proper interrogation schemes like amplitude based or optical power interrogation in contrast to approaches based on spectral based detection [26] or in general on wavelength based interrogation [17] offers the additional capability of sensing heads integration in autonomous wireless networks for increased monitoring flexibility [27].

The sensing mechanism of the polymer coated optical fibers is based on the variations of the measured power at the distal end of the fiber due to the interaction between the fiber evanescent field and the changes induced to the polymeric film by the adsorption of proteins. The measured power differs when the fiber is immersed to protein solutions of different concentrations enabling a quantitative evaluation of the protein concentration. The formation of thin and uniform polymeric layers is crucial for the development of an accurate sensor with low detection limit due to the small penetration depth of the evanescent wave. Therefore, two different deposition methods were employed in this study, the dip coating technique and direct manual casting for side deposition, in order to find the optimum conditions for the formation of high quality polymeric layers.

For the purpose of the present study, customized amphiphilic block copolymers [28] were specifically designed having both hydrophilic and hydrophobic blocks for the facilitation of protein detection and the efficient adhesion of the polymer overlayer to the optical fiber surface. More specifically, $\mathrm{PMMA}_{117^{-}}$ $b$-PDMAEMA ${ }_{16}$ and the vinyl-sulfone-functionalized $\mathrm{PMMA}_{117}-b-\mathrm{P}\left(\mathrm{DMAEMA}_{17}\right.$-st-VSTEMA $\left.{ }_{2}\right)$ amphiphilic block copolymers were prepared using a 'living' polymerization technique [29], reversible-addition fragmentation chain transfer (RAFT) polymerization [30,31], having both hydrophilic and hydrophobic blocks. Methacrylic monomers were chosen since they are easily polymerized. The hydrophilic PDMAEMA block is protonated at neutral $\mathrm{pH}$ and can electrostatically adsorb negatively charged 
molecules. The existence of vinyl-sulfone double bonds in the chemically modified $\mathrm{PMMA}_{117}-b$ $\mathrm{P}\left(\mathrm{DMAEMA}_{17}\right.$-st-VSTEMA $\left.{ }_{2}\right)$ copolymer leads to chemical binding by thiol-ene reaction with cysteine in proteins resulting in permanent immobilization of the proteins [32, 33]. The hydrophobic PMMA, a wellknown methacrylic polymer used in biomedical applications, is the non-interacting block and due to its insolubility in water it ensures the formation of stable polymeric films on the fiber surface.

Here the synthesis of the block copolymers and also the sensing mechanism of proteins based on the intrinsic polymers' properties are presented, followed by the sensors development process and the deposition characteristics of overlayers regarding their surface and adhesion properties. The sensing ability and hence, the overall performance of the fiber sensors is examined.

\section{Materials and Methods}

\subsection{Materials' Design and Synthesis}

1,4-Dioxane (anhydrous, 99.8\%), 2-(dimethylamino)ethyl methacrylate (DMAEMA, 98\%), 4-cyano-4(phenylcarbonothioylthio)pentanoic acid (CADB, 97\%), divinyl sulfone (97\%), methyl methacrylate (MMA, 99\%), THF (reagent grade, 99.9\%) tri- $n$-butylphosphine $(93.5 \%)$ and triethylamine (99\%) were purchased from Sigma Aldrich. 2,2'-Azobis(2-methylpropionitrile) (AIBN, 98\%) was purchased from Fluorochem, UK. Petroleum ether $40-60{ }^{\circ} \mathrm{C}$ (reagent grade) was purchased from Fisher Scientific. The disulfide dimethacrylate (DSDMA) cross-linker was prepared in-house using the method previously described by Rosselgong et. al. [34]. Both MMA and DMAEMA were purified before use by passing through a basic alumina (Sigma Aldrich) column to remove the MEHQ inhibitor.

All ${ }^{1} \mathrm{H}$ NMR spectroscopic analyses were performed using a Bruker Advance $400 \mathrm{~Hz}$ spectrometer. GPC analysis was performed with an Agilent Technologies 1260 Infinity GPC with Cirrus GPC software and $2 \mathrm{x}$ PLgel $5 \mu \mathrm{m}$ MIXED-C columns (PS/DVB) running at $25{ }^{\circ} \mathrm{C}$ and a flow rate of $1.0 \mathrm{~mL} / \mathrm{min}$. The eluent used was THF containing $2.0 \% \mathrm{v} / \mathrm{v}$ triethylamine and $0.05 \% \mathrm{w} / \mathrm{v}$ butylated hydroxytoluene (BHT) inhibitor. A refractive index detector operating at $30^{\circ} \mathrm{C}$ was used. The GPC was calibrated using EasiVial PMMA (2 $\mathrm{mL}$ ) standards from Agilent, with molecular weights equal to 1,010, 1,950, 6,850, 13,900, 31,110, $68,750,137,800,320,000,569,000$ and 1,048,000 g. mol ${ }^{-1}$.

\subsubsection{Synthesis of a linear $\mathrm{PMMA}_{117}$ macro chain-transfer agent (macro-CTA)}

CADB $(719.07 \mathrm{mg}, 1.500 \mathrm{mmol})$ and MMA $(18,772.50 \mathrm{mg}, 187.500 \mathrm{mmol})$ were added to a $250 \mathrm{~mL}$ round bottom flask equipped with a magnetic stirring bar and a rubber septum. 1,4-Dioxane $(34.75 \mathrm{~mL})$ was added, and the solution was bubbled with nitrogen gas for $20 \mathrm{~min}$. AIBN $(81.28 \mathrm{mg}, 0.495 \mathrm{mmol})$ was added to the flask to give a solution with a final solids content of $35 \% \mathrm{w} / \mathrm{w}$ and a molar ratio of [CADB]:[MMA]:[AIBN] of 1:125:0.3. The solution was bubbled with nitrogen gas for a further 20 min before being left to react at $70^{\circ} \mathrm{C}$ for $5 \mathrm{~h}$. The polymerization was quenched by cooling at $0^{\circ} \mathrm{C}$ and exposing the contents of the flask to air. The pure polymer was obtained by precipitation into petroleum ether and filtering to get a crude product, which was redissolved in the minimum amount of THF and further precipitated into petroleum ether before drying under vacuum. Proton nuclear magnetic resonance $\left({ }^{1} \mathrm{H}\right.$ NMR) spectroscopy gave a 93.9\% MMA monomer conversion, corresponding to a PMMA macro-CTA with a degree of polymerization (DP) of 117 and a molecular weight of 11,993 g.mol-1. GPC 
analysis yielded a slightly lower molecular weight $\left(M_{n}\right)$ of 8,150 g.mol ${ }^{-1}$ and a polydispersity index (PDI) value of 1.13 .

2.1.2 Synthesis of linear $\mathrm{PMMA}_{117}-b$-PDMAEMA ${ }_{16}$ and side chain branched disulfide-based PMMA $\mathrm{A}_{117}-b$ (PDMAEMA ${ }_{17}$-st-DSDMA ${ }_{1}$ ) amphiphilic diblock copolymers

The synthesized $\mathrm{PMMA}_{117}$ macro-CTA was subsequently chain extended with 22 equivalents of DMAEMA or a mixture (22:1) of DMAEMA and DSDMA [31] to give two amphiphilic block copolymers, the cationic $\mathrm{PMMA}_{117}-b$-PDMAEMA ${ }_{16}\left(M_{\mathrm{n}}=9,960 \mathrm{~g} \cdot \mathrm{mol}^{-1}, \mathrm{PDI}=1.17\right)$ and the branched, disulfide-based cationic $\mathrm{PMMA}_{117}-b$-(PDMAEMA $17^{-}$-st-DSDMA $\left.{ }_{1}\right)\left(M_{\mathrm{n}}=10,200 \mathrm{~g} \cdot \mathrm{mol}^{-1}, \mathrm{PDI}=1.28\right)$, respectively (Figure 1$)$. The GPC chromatograms of the two synthesized polymers are presented in Figure 4.

For the PMMA $\mathrm{P}_{117}-b$-PDMAEMA ${ }_{16}$ block copolymer, PMMA $_{117}(1918.95 \mathrm{mg}, 0.160 \mathrm{mmol})$ and DMAEMA (553.38 $\mathrm{mg}, 3.520 \mathrm{mmol}$ ) were each added to a $100 \mathrm{~mL}$ round bottom flask along with a magnetic stirring bar and the flask was sealed using a rubber septum. 1,4-Dioxane $(9.92 \mathrm{~mL})$ was added in the flask before the solution was bubbled with nitrogen gas for $20 \mathrm{~min}$. AIBN $(8.67 \mathrm{mg}, 0.053 \mathrm{mmol}$ ) was then added to the mixture and the solution was further degassed for 20 min bubbling with nitrogen gas. The reagents were left to react at $70^{\circ} \mathrm{C}$ for $11 \mathrm{~h}$ before the reaction was quenched in an ice bath. The pure $\mathrm{PMMA}_{117}-b$-PDMAEMA 16 block copolymer was obtained by precipitation in petroleum ether.

For the PMMA $117-b$-(PDMAEMA 1 -st-DSDMA ${ }_{1}$ ) block copolymer, PMMA $_{117}(5996.71 \mathrm{mg}, 0.500 \mathrm{mmol}$ ), DMAEMA (1729.31 mg, $11.000 \mathrm{mmol}$ ) and DSDMA (145.21 mg, $0.500 \mathrm{mmol}$ ) were added separately to a $100 \mathrm{~mL}$ round bottom flask containing a magnetic stirring bar, and sealed with a rubber septum. 1,4Dioxane $(31.59 \mathrm{~mL})$ was added and the contents were bubbled with nitrogen gas for $20 \mathrm{~min}$. AIBN (27.09 $\mathrm{mg}, 0.165 \mathrm{mmol}$ ) was added to the mixture and the solution was further degassed for 20 min using nitrogen gas. The reaction was left to proceed at $70{ }^{\circ} \mathrm{C}$ for $13 \mathrm{~h}$ before quenching at $0{ }^{\circ} \mathrm{C}$. The reaction product was purified by precipitation in petroleum ether.

The PMMA ${ }_{117}-b$-PDMAEMA 16 block copolymer would serve as a control to compare the effectiveness of cationic/thiol and cationic/vinyl sulfone overlayers to purely cationic overlayers with respect to their protein binding capabilities. The PMMA $\mathrm{PM}_{117}-b$-(PDMAEMA $\left.17-s t-\mathrm{PSDMA}_{1}\right)$ block copolymer was used in the preparation of thiol-based and vinyl sulfone-based amphiphilic block copolymers, as described below.

\subsubsection{Synthesis of thiol-functionalized $\mathrm{PMMA}_{117}-b$-(PDMAEMA ${ }_{17}$-st-TEMA $\left.{ }_{2}\right)$ and vinyl-sulfone-} functionalized PMMA $_{117}-b$-(PDMAEMA ${ }_{17}$-st-VSTEMA $)_{2}$ amphiphilic diblock copolymers

The reaction scheme for the preparation of the thiol-functionalized and the vinyl-sulfone functionalized polymers of this study is presented in Figure 2 and their GPC chromatograms are presented in Figure 4.

$4 \mathrm{~g}$ of the branched, disulfide-based $\mathrm{PMMA}_{117}-b-\mathrm{P}\left(\mathrm{DMAEMA}_{22}\right.$-st-DSDMA $\left.{ }_{1}\right)$ block copolymer $(0.202 \mathrm{mmol}$ of disulfide bonds) were dissolved in $160 \mathrm{~mL}$ THF in a250 mL two-necked round-bottom flask. The flask was equipped with a magnetic stirring bar and sealed with a rubber septum. The mixture was bubbled with nitrogen gas for $20 \mathrm{~min}$ and placed in an oil bath at $30{ }^{\circ} \mathrm{C}$. Separately, a $10 \mathrm{~mL}$ stock solution containing $\mathrm{Bu}_{3} \mathrm{P}\left(0.50 \mathrm{~mL}, 10.0\right.$ molar equivalents relative to the disulfide bonds) and $\mathrm{Et}_{3} \mathrm{~N}(0.17 \mathrm{~mL}, 6.0$ molar equivalents relative to the disulfide bonds) in THF was degassed at room temperature with nitrogen gas for 5 min. $5 \mathrm{~mL}$ of the $10 \mathrm{~mL}$ stock solution was withdrawn and added to the flask containing the block copolymer in order to induce cleavage of the disulfide bonds to their corresponding thiols. The contents were left to react at $30{ }^{\circ} \mathrm{C}$ for $24 \mathrm{~h}$. This resulted in the conversion of 1 eq. of 
DSDMA to 2 eq. of TEMA. An $80 \mathrm{~mL}$ sample of the PMMA ${ }_{117}-b$-(PDMAEMA 17 -st-TEMA $)$ block copolymer $\left(M_{\mathrm{n}}=11,600 \mathrm{~g} \cdot \mathrm{mol}^{-1}, \mathrm{PDI}=1.30\right)$ was extracted from the reaction flask under nitrogen. To the remaining $80 \mathrm{~mL}$ of thiol-functionalized polymer solution, $2 \mathrm{~mL}$ of a $3 \mathrm{~mL}$ degassed stock solution of divinyl sulfone ( $617.53 \mathrm{mg}, 15$ eq. relative to the thiol $-\mathrm{SH}$ group) in THF were added. The resulting mixture was stirred at $30{ }^{\circ} \mathrm{C}$ for $15 \mathrm{~h}$ in order to convert the TEMA monomer units into VSTEMA monomer units. The reaction resulted in the formation of the vinyl-sulfone-functionalized $\mathrm{PMMA}_{117}-b-\mathrm{P}\left(\mathrm{DMAEMA}_{22}\right.$-stVSTEMA 2 ) block copolymer $\left(M_{\mathrm{n}}=10,700 \mathrm{~g} \cdot \mathrm{mol}^{-1}, \mathrm{PDI}=1.25\right)$.

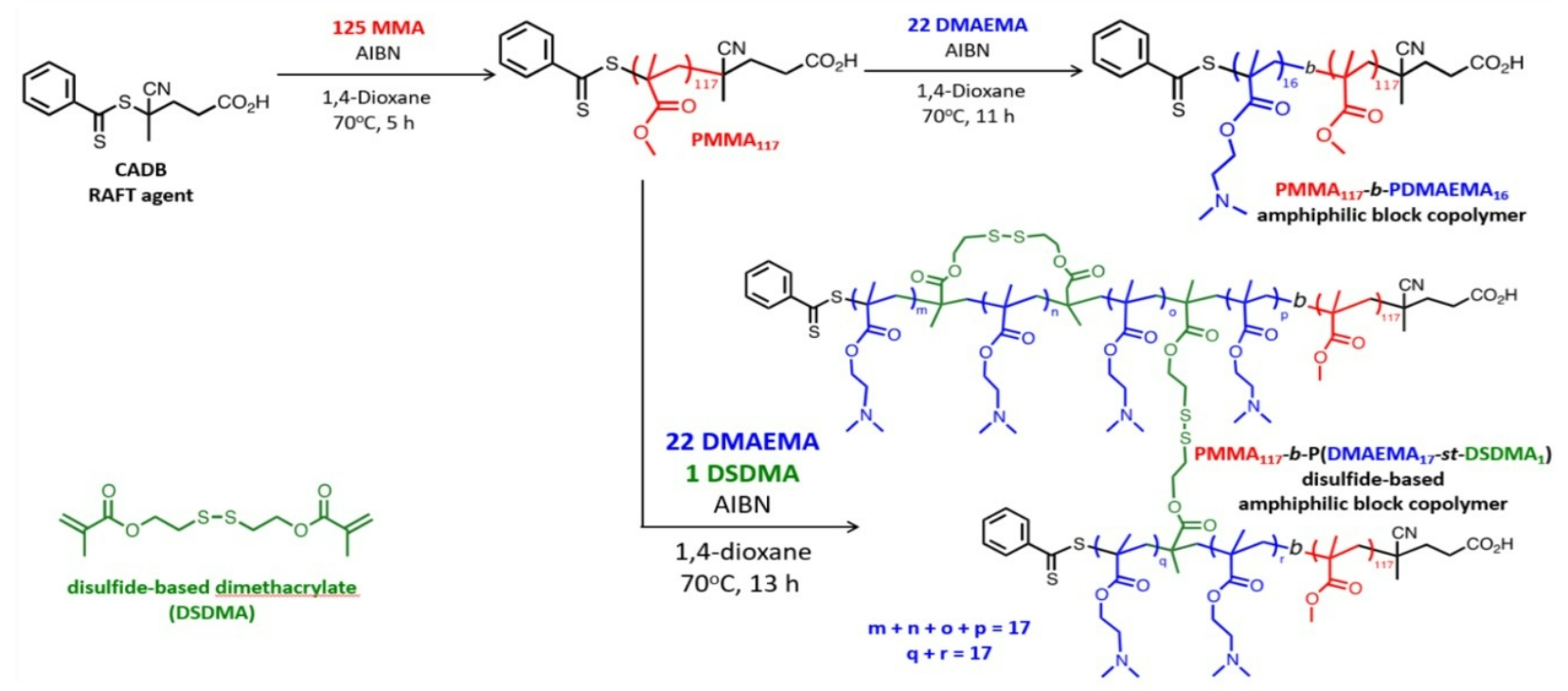

Figure 1. Synthesis of PMMA macro-CTA, linear $\mathrm{PMMA}_{117}-b-\mathrm{PDMAEMA}_{16}$ amphiphilic block copolymer and branched disulfide-based $\mathrm{PMMA}_{117}-b-\left(\mathrm{PDMAEMA}_{17}-\mathrm{st}-\mathrm{DSDMA}_{1}\right)$ amphiphilic diblock copolymer by RAFT polymerization.

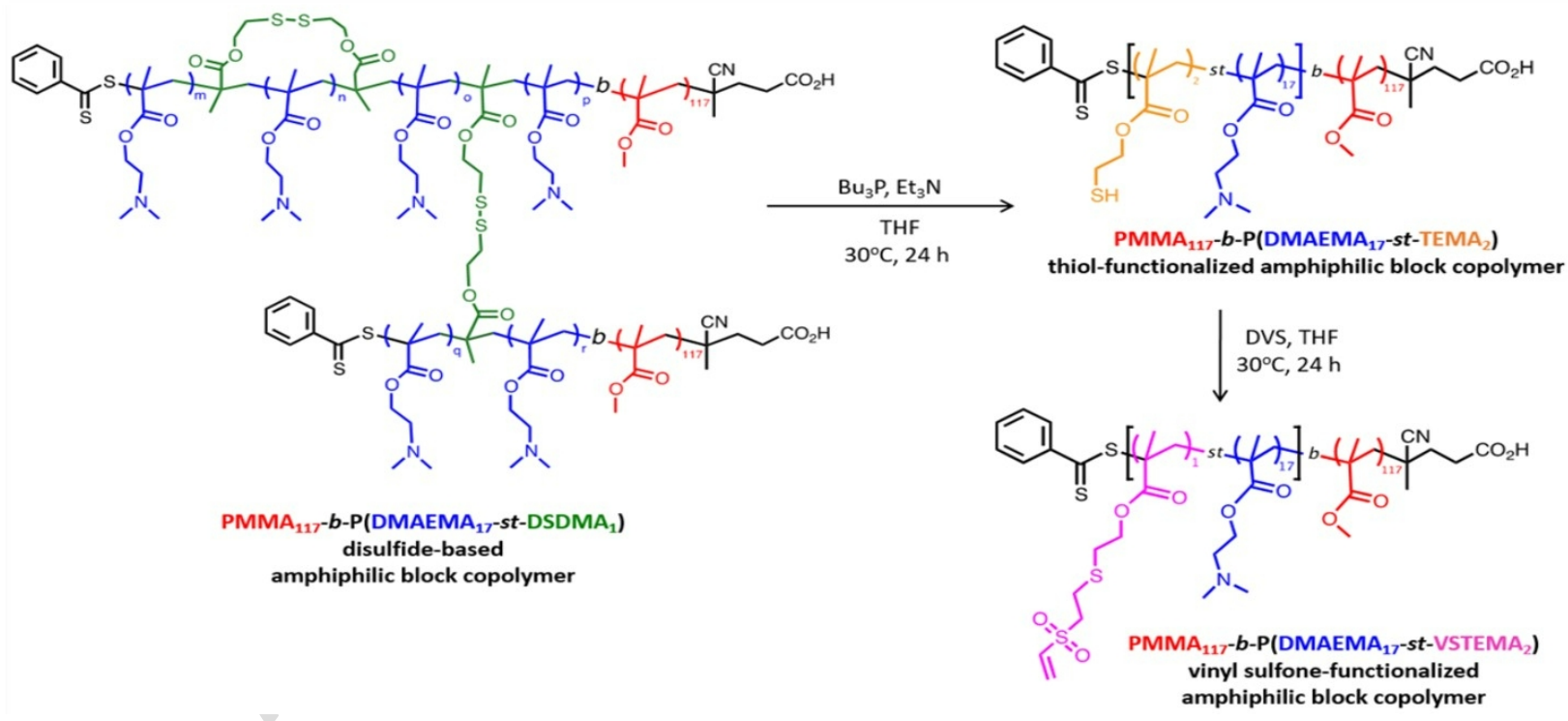

Figure 2. Preparation of thiol-functionalized linear $\mathrm{PMMA}_{117}-b$ - $\left(\mathrm{PDMAEMA}_{17}-\mathrm{St}-\mathrm{TEMA}_{2}\right)$ amphiphilic block copolymer by reductive cleavage of the disulfide bonds in the branched $\mathrm{PMMA}_{117}-b-\left(\mathrm{PDMAEMA}_{17}-s t-\mathrm{DSDMA}_{1}\right)$ using $\mathrm{Bu}_{3} \mathrm{P}$ and of vinyl-sulfone-functionalized linear $\mathrm{PMMA}_{117}-b$-(PDMAEMA 17 -St-VSTEMA $)_{2}$ amphiphilic diblock copolymer by in situ conjugation of excess divinyl sulfone to the thiol-functionalized polymer. 


\subsection{Sensor's Characterization Experimental setup}

The experimental setup for sensing heads characterization consists of a functionalized silica fiber connected to a Thorlabs M625F1 LED light source operating at $650 \mathrm{~nm}$ with maximum output power of $10 \mathrm{~mW}$. The sensing region of the fiber is immersed in solutions with different protein concentrations and the signal is recorded at the fiber's distal end by a Thorlabs PM100D power meter connected to a computer. The setup is presented schematically in Figure 3.
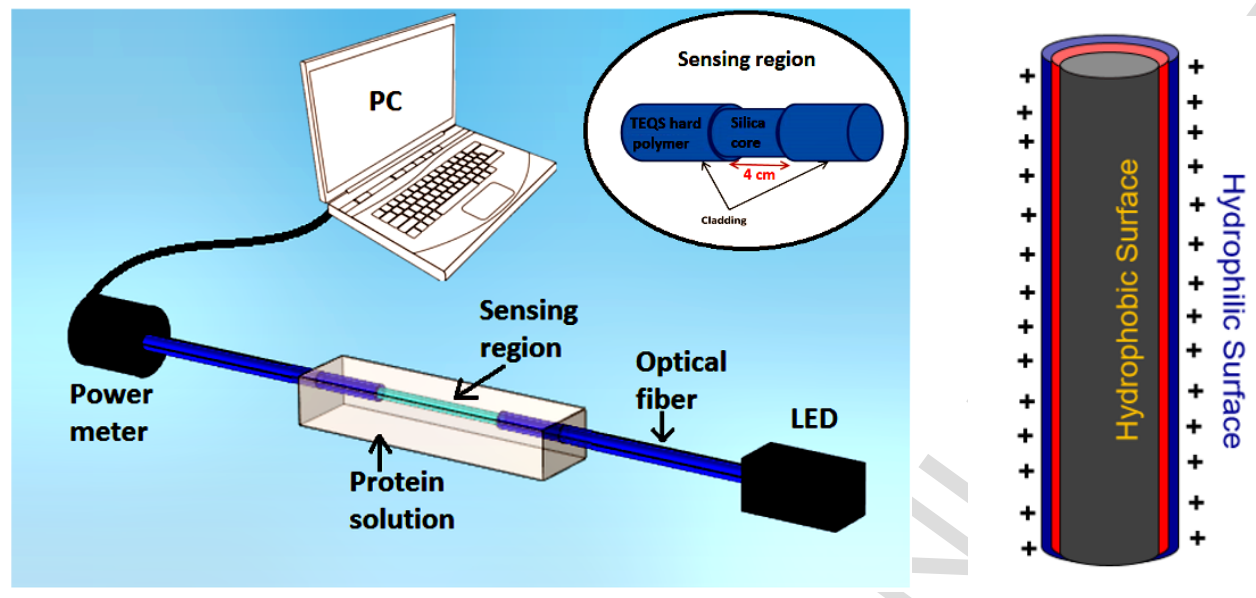

Figure 3. Schematic representation of the experimental setup (left), and of the functionalized fiber (right).

Due to the opposite charges of the sensing material and the measured protein, the protein is electrostatically bound onto the positively charged hydrophilic surface of polymeric layer. The protein adsorption from the copolymer at the fiber's surface changes both the refractive index as well as the thickness of the film. Due to the interaction between the evanescent field and the polymeric film these changes cause a variation in the output power measured at the fiber's distal end.

\section{Results and Discussion}

\subsection{Characterization of the developed copolymers}

For the confirmation of the copolymers' structure GPC analysis was performed. The GPC chromatograms of the polymer samples (Figure 4) show a shift in the elution time between the PMMA ${ }_{117}$ macro-CTA and the four diblock copolymers, indicative of an increase in the molecular weight of the polymers. The peak corresponding to the disulfide-functionalized block copolymer had a slight shoulder at higher molecular weight (lower elution time) due to intermolecular cross-linking of disulfide groups between polymer chains. This was also the case for the peak corresponding to the thiol-functionalized polymer, which is due to reformation of disulfide bonds from exposure of the thiols to atmospheric oxygen. The molecular weight values determined by GPC also indicate some intermolecular cross-linking in the thiolfunctionalized polymer. More specifically, the $M_{n}$ value of the thiol-functionalized polymer $\left(M_{n}=11,600\right.$ g. $\left.\mathrm{mol}^{-1}\right)$ was found to be slightly higher than the ones for the disulfide-functionalized polymer $\left(M_{\mathrm{n}}\right.$ $\left.=10,200 \mathrm{~g} \cdot \mathrm{mol}^{-1}\right)$ or the vinyl-sulfone functionalized polymer $\left(M_{\mathrm{n}}=10,700 \mathrm{~g} \cdot \mathrm{mol}^{-1}\right)$ as is presented in Table 1. 


\begin{tabular}{|c|c|c|c|c|c|c|c|c|}
\hline Entry & Target copolymer composition & $\begin{array}{c}\% \\
\text { Conversion }^{\mathrm{a}}\end{array}$ & $\begin{array}{l}\text { DPa } \\
\text { MMA }\end{array}$ & $\begin{array}{c}\text { DPa } \\
\text { DMAEMA }\end{array}$ & $\begin{array}{c}\text { DPa } \\
\text { DSDMA }\end{array}$ & $\begin{array}{c}\mathrm{MW}^{\mathrm{a}} \\
\left(\mathrm{g} \cdot \mathrm{mol}^{-1}\right)\end{array}$ & $\begin{array}{c}\mathrm{M}_{\mathrm{n}}^{\mathrm{b}} / \\
\left(\mathrm{g} \cdot \mathrm{mol}^{-1}\right)\end{array}$ & PDI \\
\hline 1 & $\mathrm{PMMA}_{125}$ & 93.9 & 117 & / & / & 12,000 & 8,150 & 1.13 \\
\hline 2 & PMMA $_{117}$-b-PDMAEMA 22 & 74.2 & 117 & 16 & / & 14,700 & 9,960 & 1.17 \\
\hline 3 & PMMA $_{117}$-b-P(DMAEMA $\left.\left.22^{- \text {st-DSDMA }}\right)_{1}\right)$ & 76.4 & 117 & 17 & 1 & 15,000 & 10,200 & 1.28 \\
\hline 4 & PMMA $_{117}$-b-P(DMAEMA 22 -st-TEMA $\left.{ }_{2}\right)$ & / & 117 & 17 & 2 & 15,000 & 11,600 & 1.30 \\
\hline 5 & PMMA $_{117}$-b-P(DMAEMA 22 -st-VSTEMA $\left.{ }_{2}\right)$ & / & 117 & 17 & 2 & 15,200 & 10,700 & 1.25 \\
\hline
\end{tabular}

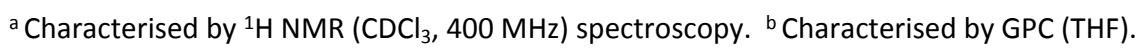

Table 1. Characterization of polymers. The low polydispersity index PDI demonstrates the well defined structure of fabricated block copolymers.

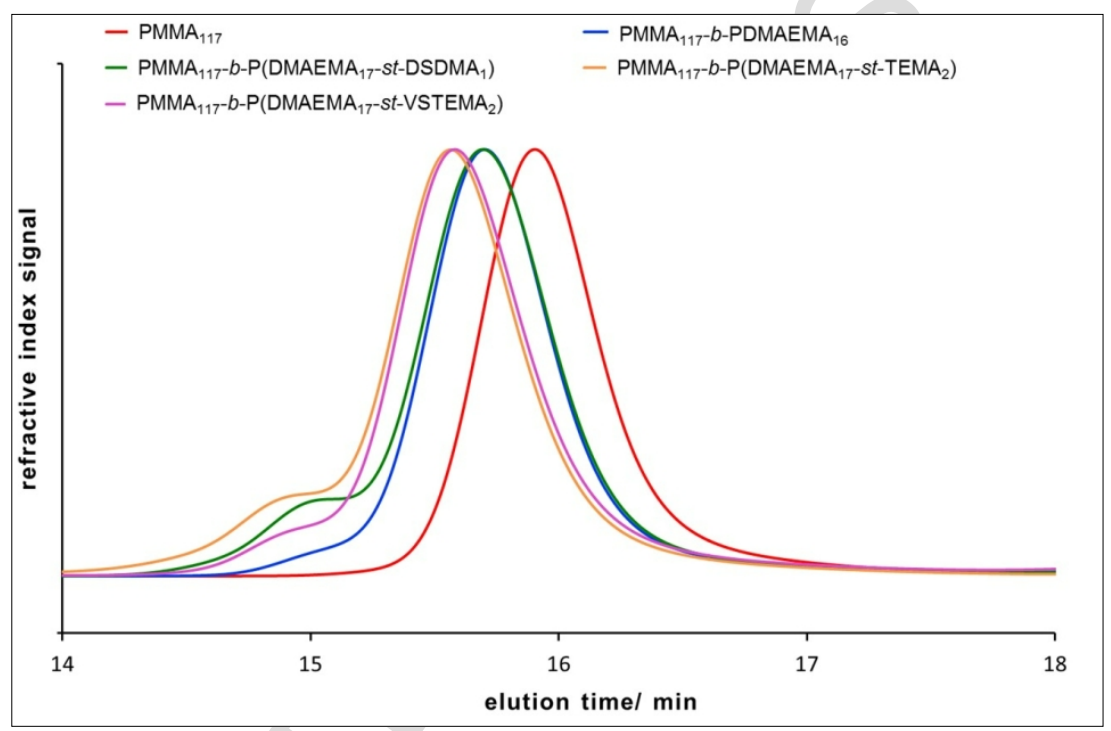

Figure 4. GPC (THF) chromatogram of the PMMA-macroCTA and the amphiphilic block copolymers.

The two synthesized polymers are presented in Figure 5 showing the groups that interact with the BSA protein. The PDMAEMA block of the PMMA ${ }_{117}-b$-PDMAEMA ${ }_{16}$ amphiphilic block copolymer is extensively protonated at low $\mathrm{pH}$ leading to electrostatic binding of negatively charged BSA molecules to the dimethylamino group. The presence of vinyl-sulfone double bonds to the PMMA $_{117}-b$ - $\left(\right.$ PDMAEMA $_{17}$-stVSTEMA $A_{2}$ ) additionally leads to chemical binding by thiol-ene reaction with cysteine in proteins. 


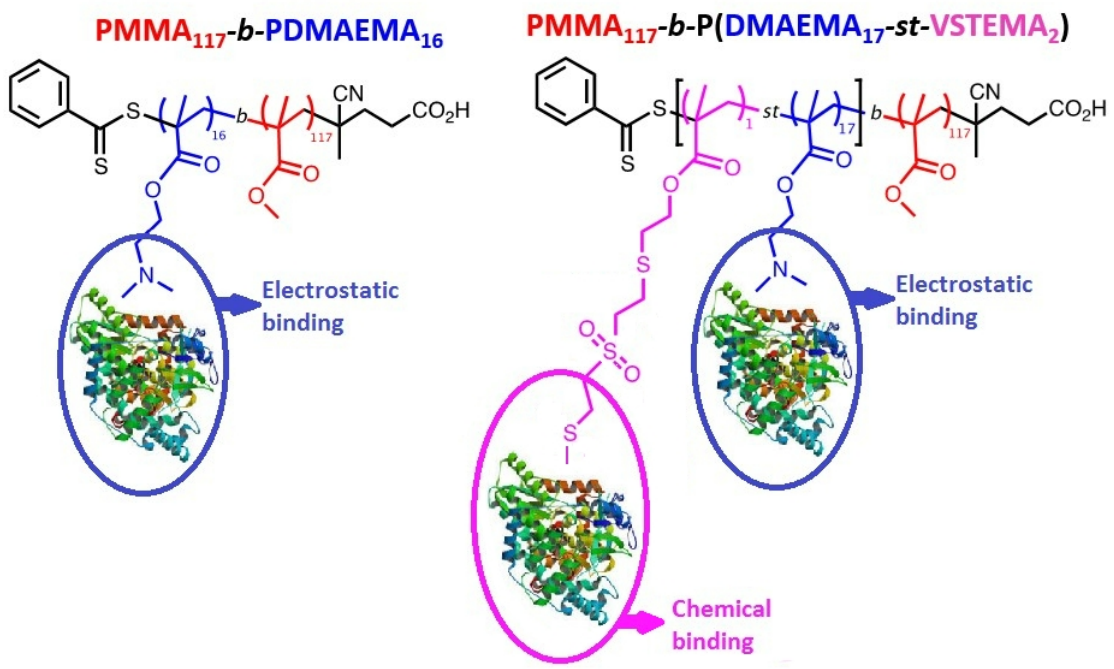

Figure 5. The two synthesized polymers and the corresponding groups interacting with the BSA protein.

\subsection{Sensors' development}

For the development of fiber optic sensing heads, large core and multimoded silica optical fibers of 600 $\mu \mathrm{m}$ silica core (FT600EMT, purchased from Thorlabs) with removable polymer cladding was used. For the functionalization of the fibers, both the protective jacket and the cladding were mechanically removed over a length of $4 \mathrm{~cm}$ exposing the core. The exposed region was cleaned with acetone and dried before the deposition of the polymeric material. The block copolymer solutions were deposited on the exposed silica cores of the fibers using either direct side polymer deposition or the dip coating technique. For the deposition, block copolymer solutions of $1.0 \% \mathrm{w} / \mathrm{v}, 0.5 \% \mathrm{w} / \mathrm{v}$ and $0.2 \% \mathrm{w} / \mathrm{v}$ concentration were used. After the polymeric layer deposition, the sensing region of the fiber was immersed into a buffer solution at $\mathrm{pH} 7$ to get a positively charged surface on the top of the polymeric film which could adsorb the negatively charged at neutral pH BSA protein.

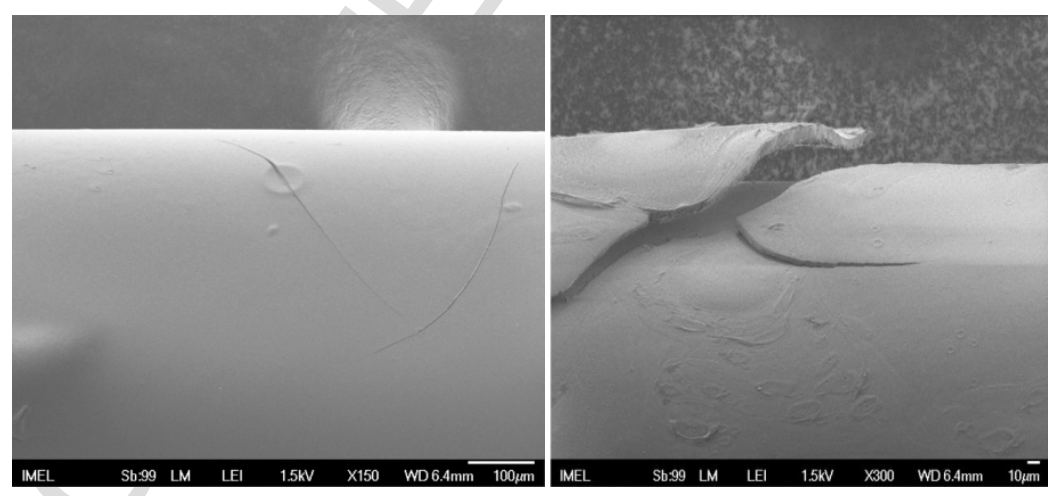

Figure 6. Indicative SEM images of silica optical fibers covered with thick overlayer of $\mathrm{PMMA}_{117}-b-\mathrm{PDMAEMA}{ }_{16}$ amphiphilic block copolymer using direct side polymer deposition.

For the direct side polymer deposition $\sim 1 \mu$ of the block copolymer was deposited on the fiber using a high precision automatic pipette. The fiber was placed horizontally and the pipette was moving vertically to the fiber with a velocity of $20 \mathrm{~mm} / \mathrm{s}$. A systematic study for the development of different overlayers on fibers surface was performed in order to identify optimal conditions. The scanning electron 
microscopy (SEM) images in Figure 6 (obtained from SEM instrument JEOL JSM -7401f FESEM) show that the polymeric films formed with $1.0 \% \mathrm{w} / \mathrm{v} \mathrm{PMMA}_{117}-b$-PDMAEMA ${ }_{16}$ amphiphilic block copolymer solution using direct side polymer deposition are quite thick $(\sim 7 \mu \mathrm{m})$. The non-optimum bonding with the silica surface and also the different Young's modulus and thermal expansion coefficients of silica and polymer layer, lead to different mechanical behavior with temperature and consequently to formation of cracks.

The side deposition was employed as it would be better suited for the selective deposition of a layer in a predetermined length of the fiber without the need to dip the entire length of the fiber affecting thus the deposition uniformity. However, the control was not optimum resulting thus in thick layers. For the formation of thin and mechanically robust polymeric layers the dip coating technique was then employed. As an initial characterization procedure polymeric layers of $\mathrm{PMMA}_{117}-b$-PDMAEMA 16 solutions with different concentrations were deposited on glass slides with dip coating in order to measure the film thickness with a profilometer (KLA-Tencor Alpha-step IQ Surface Profiler). The evaluation was performed using glass slides since the thickness of the polymeric film could not be measured directly on the fiber with the profilometer due to the curvature of the fiber surface. The glass slides were inserted vertically in the polymeric solution for 3 seconds and were left to dry in room temperature for $1 \mathrm{~h}$ before measurement. The velocity of insertion was $20 \mathrm{~mm} / \mathrm{s}$. Figure 7 shows the linear dependence between the film thickness and the concentration of the $\mathrm{PMMA}_{117}-b-\mathrm{PDMAEMA}_{16}$ solution, as well as the number of dips. The films obtained with the dip coating technique are very thin, with thicknesses ranging from $\sim 20 \mathrm{~nm}$ to $\sim 75 \mathrm{~nm}$ for $\mathrm{PMMA}_{117}-b-\mathrm{PDMAEMA}_{16}$ solutions of $0.2 \% \mathrm{w} / \mathrm{v}$ and $1 \% \mathrm{w} / \mathrm{v}$, respectively, for a single dip.
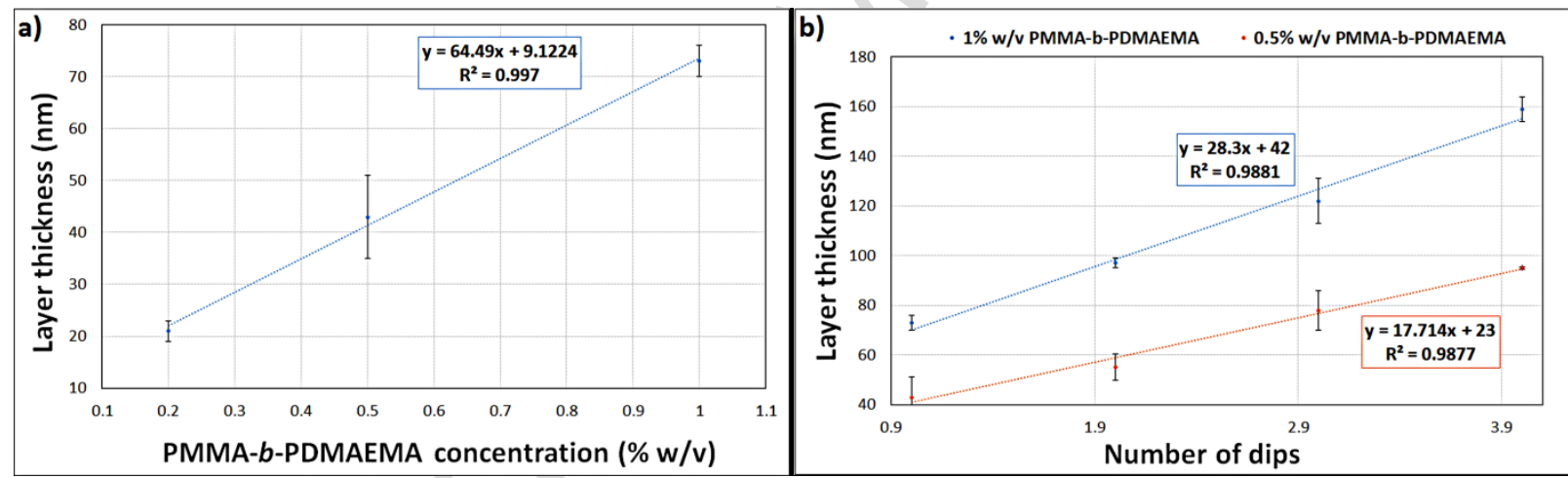

Figure 7. Thickness of the $\mathrm{PMMA}_{117}-b-\mathrm{PDMAEMA}_{16}$ polymeric film as a function of the PMMA $\mathrm{PM}_{117}-b-\mathrm{PDMAEMA}_{16}$ solution concentration (a) and of the number of dips (b).

SEM characterization of an optical fiber coated with $0.2 \% \mathrm{w} / \mathrm{v} \mathrm{PMMA}_{117}-b-\mathrm{PDMAEMA}_{16}$ solution was also performed in order to measure the thickness of the polymeric layer (Figure 8). The fiber was also inserted vertically in the polymeric solution for 3 seconds and was left to dry in room temperature for $1 \mathrm{~h}$ before measurement. The velocity of insertion was $20 \mathrm{~mm} / \mathrm{s}$. The thickness was $\sim 30 \mathrm{~nm}$ and it was measured on a cross-section of the fiber parallel to the fiber's axis. The fiber, due to its large diameter behaves similarly to a flat surface; hence the measured film thickness is close to the value measured on the flat surface of the glass slide. 

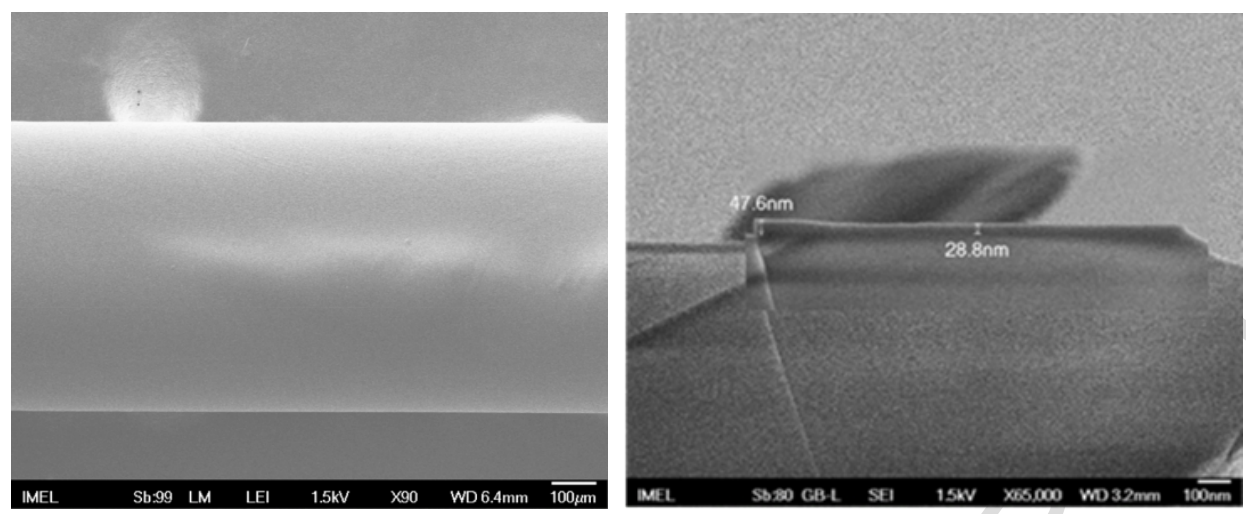

Figure 8. SEM images of silica optical fibers covered with $0.2 \% \mathrm{w} / \mathrm{v} \mathrm{PMMA}_{117}-b-\mathrm{PDMAEMA}_{16}$ amphiphilic block copolymer solution using the dip coating technique for the deposition of the polymer.

\subsection{Performance of the PMMA $_{117}-b$-PDMAEMA 16 block copolymer}

For the protein detection experiments optical fibers coated with both $\mathrm{PMMA}_{117}-b-\mathrm{PDMAEMA} \mathrm{A}_{16}$ and $\mathrm{PMMA}_{117}-b-\mathrm{P}\left(\mathrm{DMAEMA}_{17}-\mathrm{VSTEMA}_{2}\right)$ copolymers were evaluated over different $\mathrm{BSA}$ concentrations in buffer solutions (BSA purchased from Sigma-Aldrich in form of lyophilized powder, essentially globulin free, $\geq 99 \%, A 7638$ SIGMA). The buffer solution was used in order to simulate the acidity and salinity of the biological liquids. The coated fibers are firstly immersed in buffer solution to take the reference intensity value $\left(I_{\text {ref }}\right)$. Then the sensor's response, defined as:

$$
\operatorname{Response}(\%)=\frac{I_{\text {sig }}-I_{\text {ref }}}{I_{\text {ref }}} \times 100
$$

where $I_{\text {sig }}$ the intensity measured for a BSA solution, is calculated.

The first experiments were performed with optical fibers coated with $1 \% \mathrm{w} / \mathrm{v} \mathrm{PMMA}_{117}-b$-PDMAEMA 16 amphiphilic block copolymer solution using direct side polymer deposition. The fiber was immersed in BSA solutions with different concentrations. After each immersion the fiber was washed with buffer solution. The results are presented in Figure 9 (a).
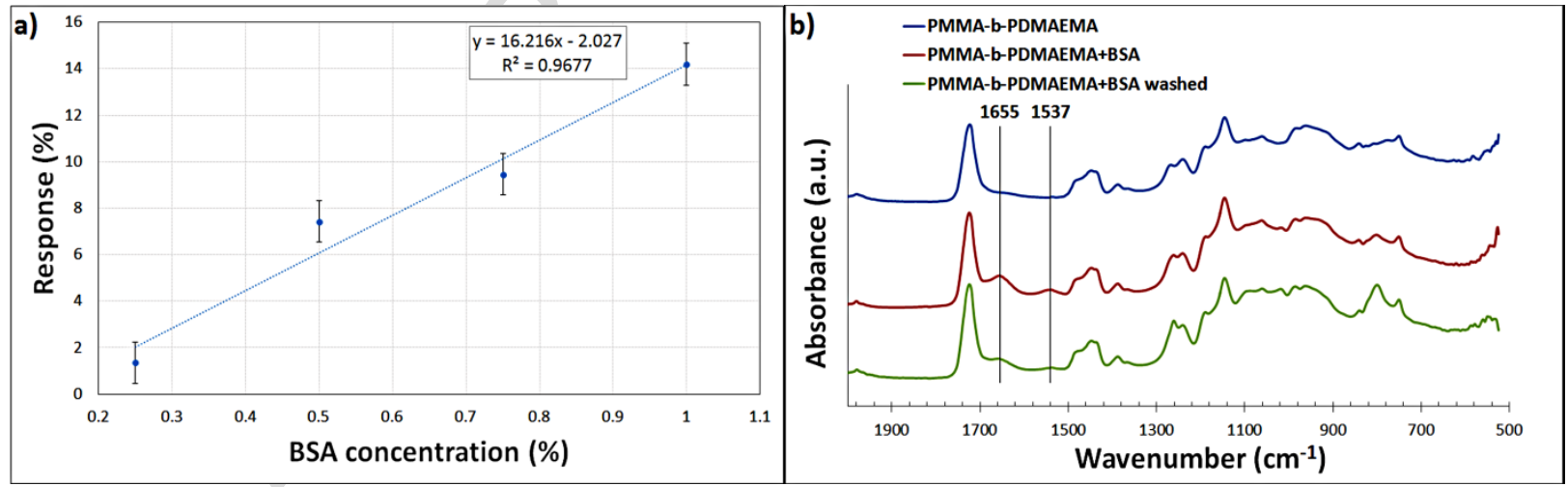

Figure 9. a) Absolute response for different $B S A$ concentrations of an optical fiber coated with $1 \% \mathrm{w} / \mathrm{v} P M A_{117}-b-$ PDMAEMA $_{16}$ amphiphilic block copolymer solution using direct side polymer deposition resulting in an overlayer thickness of $\sim 7 \mu \mathrm{m}$. b) ATR-FTIR spectrums of the fiber sensor coated with PMMA $_{117}-b$-PDMAEMA 16 polymer 
before (blue) and after (red) BSA adsorption. The green line is the spectrum after washing the sensor with the absorbed BSA with buffer solution.

Such thick overlayers $(\sim 7 \mu \mathrm{m})$ were efficient for monitoring only high BSA concentrations ranging from $0.25 \% \mathrm{w} / \mathrm{v}-1 \% \mathrm{w} / \mathrm{v}$, limiting the sensitivity by the weak interaction between the evanescent field and the protein due to the high film thickness. ATR-FTIR analysis was performed to confirm the presence of the BSA's adsorption bands (amide bond frequencies at 1655 and $1537 \mathrm{~cm}^{-1}$ ) and thus prove that the protein is efficiently adsorbed by the $\mathrm{PMMA}_{117}-b$-PDMAEMA 16 copolymer (Figure 9 (b)). Despite the reversible electrostatic binding mechanism we noticed that after washing the fiber there was still a residual presence of BSA on the polymeric film.

In order to increase the detection limit and increase the sensors' lifetime by avoiding the degradation of the layer after excessive use, the experimental procedure was repeated with an optical fiber coated with $0.2 \% \mathrm{w} / \mathrm{v} \mathrm{PMMA}_{117}-b-\mathrm{PDMAEMA}_{16}$ amphiphilic block copolymer solution using the dip coating technique for the deposition. The sensor's response as presented in Figure 10 (a) shows that the detection limit was indeed decreased by one order of magnitude (BSA concentrations ranging from $0.025 \%$ to $0.1 \%$ $\mathrm{w} / \mathrm{v}$ ) due to the thin polymeric layer. Furthermore, due to the improved quality of the film, the sensor exhibited good reversibility. The response presented is not linear due to the fact that the fiber was not washed after each immersion.
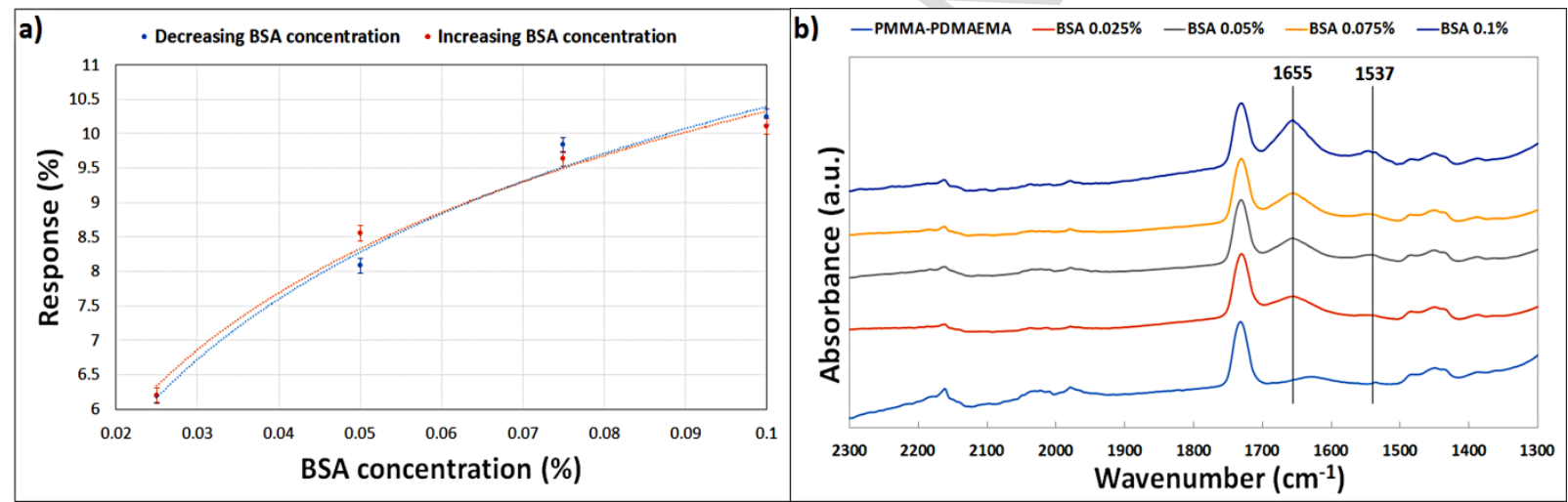

Figure 10. a) Absolute response for different BSA concentrations of an optical fiber coated with $0.2 \% \mathrm{w} / \mathrm{v}$ $\mathrm{PMMA}_{117}-b$-PDMAEMA ${ }_{16}$ amphiphilic block copolymer solution using the dip coating technique resulting in an overlayer thickness of $\sim 30 \mathrm{~nm}$. b) ATR-FTIR spectrums after immersion to solutions with different BSA concentration.

The response of BSA detection in Figure 10a, as derived by consecutive immersions to different BSA concentrations without intermediate steps of BSA washing, represents more accurately a realistic scenario of continuously varying BSA concentration. The response of the sensor to different BSA concentrations was also evaluated with ATR-FTIR measurements. Figure 10 (b) shows increased BSA adsorption after immersion to solutions with higher BSA concentration.

\subsection{Performance of the PMMA $_{117}-b-P\left(D_{M A E M A}{ }_{17}\right.$ VSTEMA $\left._{2}\right)$ block copolymer}

The experiments were repeated using an optical fiber coated with $1 \% \mathrm{w} / \mathrm{v} \mathrm{PMMA}_{117}-b-\mathrm{P}\left(\mathrm{DMAEMA}_{17^{-}}\right.$ $\mathrm{VSTEMA}_{2}$ ) amphiphilic block copolymer solution with direct side polymer deposition resulting in an overlayer thickness of $\sim 7 \mu \mathrm{m}$. The $\mathrm{PMMA}_{117}-b$-P(DMAEMA $\left.{ }_{17}-\mathrm{VSTEMA}_{2}\right)$ copolymer, due to its vinyl- 
sulfone double bonds, should give an additional non-reversible chemical binding mechanism to the negatively charged proteins, further to the cationic group reversible electrostatic mechanism.
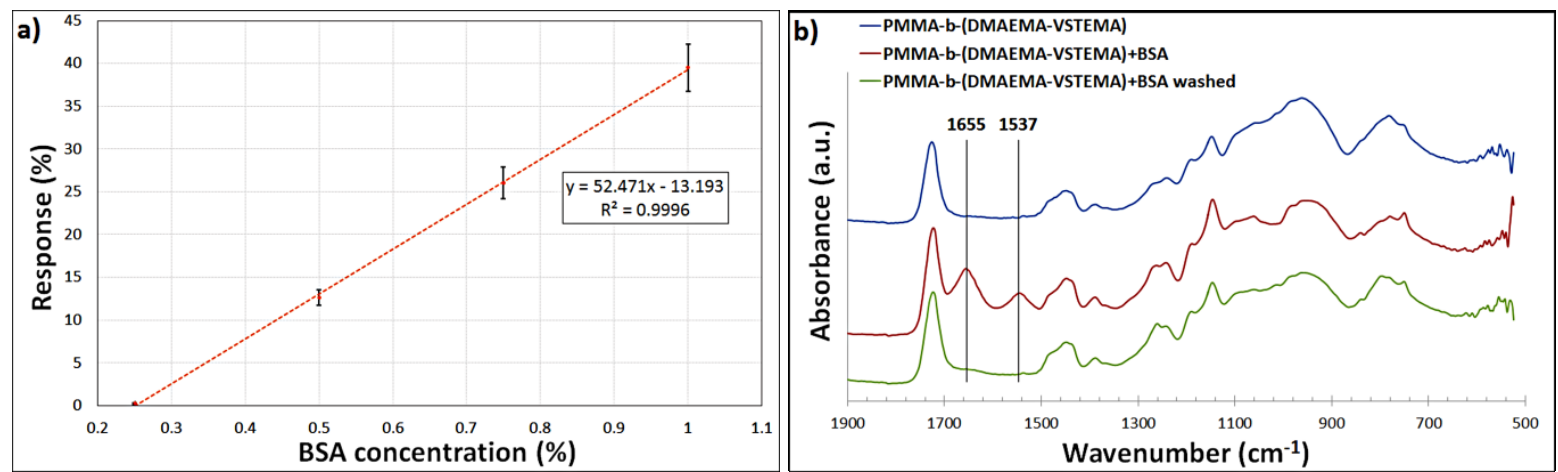

Figure 11. a) Absolute response for different BSA concentrations of an optical fiber coated with $1 \% \mathrm{w}^{\mathrm{N}} \mathrm{vMM \textrm {P } _ { 1 1 7 ^ { - } }}$ $b$-P(DMAEMA ${ }_{17}-$ VSTEMA $\left._{2}\right)$ amphiphilic block copolymer. b) ATR-FTIR spectrums of the PMMA PM- $_{117}-\mathrm{P}\left(\mathrm{DMAEMA}_{17}-\right.$ VSTEMA $A_{2}$ ) coated fiber before (blue) and after (red) BSA adsorption. The green line is the spectrum after washing the sensor with the adsorbed BSA with buffer solution.

The fiber was immersed in BSA solutions with different concentrations. After each immersion, the fiber was washed with buffer solution. The results are presented in Figure 11 (a).

We can confirm that due to additional mechanism of permanent covalent binding, the response of $\mathrm{PMMA}_{117}-b-\mathrm{P}\left(\mathrm{DMAEMA}_{17}-\mathrm{VSTEMA}_{2}\right)$ is considerably higher than the response of $\mathrm{PMMA}_{117}-b$ PDMAEMA $_{16}$ block copolymer (Figure 10). However, a direct comparison and the determination of chemical binding contribution would not be possible as there are also other parameters like overlayer thickness and uniformity that affect the responsivity.

In order to verify the $\mathrm{PMMA}_{117}-b-\mathrm{P}\left(\mathrm{DMAEMA}_{17}-\mathrm{VSTEMA}_{2}\right)$ sensing performance, ATR-FTIR measurements were also performed. The results, presented in Figure 11 (b), demonstrate the clear presence of BSA protein as efficiently adsorbed by the polymer. However we can observe the drastic decrease of adsorption peaks of BSA after washing the fiber with buffer solution despite the fact that the $\mathrm{PMMA}_{117}-b-\mathrm{P}\left(\mathrm{DMAEMA}_{17}-\mathrm{VSTEMA}_{2}\right)$ copolymer should lead to permanent immobilization of proteins. This could be attributed to the composition of the copolymers as there are only $2 / 19$ units of the hydrophilic block VSTEMA compared to $17 / 19$ of DMAEMA. This implies that only a very small amount of protein is covalently bound compared to that which is electrostatically bound.

It was observed that the excessive use (resulted after 20 consecutive measurements) of fiber heads in aqueous solutions was causing a gradual degradation for the relatively thicker films of both $\mathrm{PMMA}_{117}-b$ PDMAEMA $_{16}$ and PMMA $_{117}-b-\mathrm{P}\left(\mathrm{DMAEMA}_{17}-\mathrm{VSTEMA}_{2}\right)$ block copolymers, in the form of cracks, as is indicatively presented in the SEM images of Figures 6 and 12. Probably the highly hydrophilic nature of the overlayer can cause a degree of swelling leading to cracks, delamination or even partial deformation. 

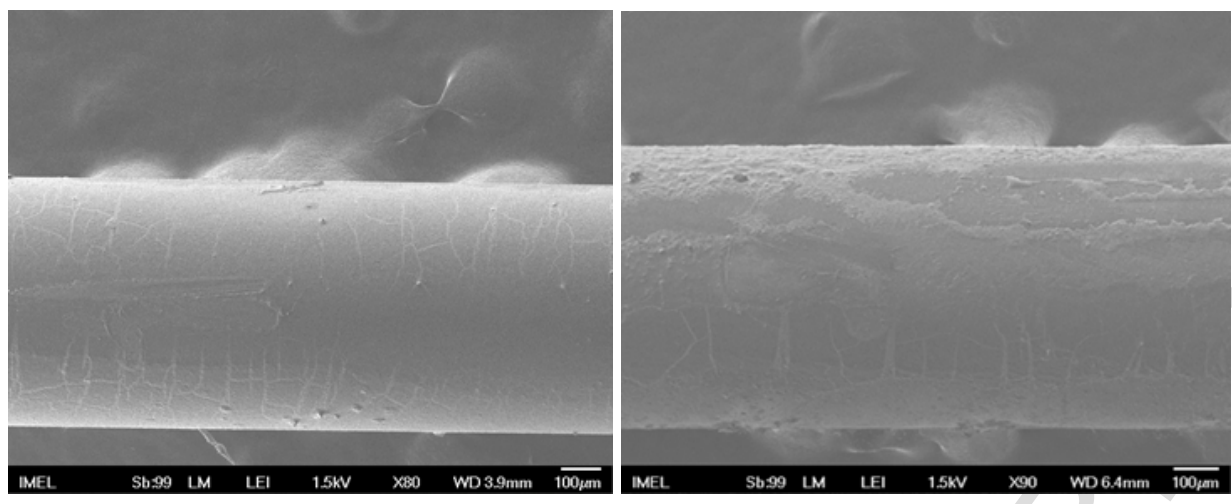

Figure 12. SEM images of a fibers covered with $\mathrm{PMMA}_{117}-b$-PDMAEMA $A_{16}$ (left) and $\mathrm{PMMA}_{117}-b-\mathrm{P}\left(\mathrm{DMAEMA}_{17^{-}}\right.$ VSTEMA $_{2}$ ) (right) polymer after excessive experimental use of 20 consecutive measurements.

It should be noted that the ATR-FTIR analysis provides mostly qualitative information on the mechanism of BSA detection and therefore the relevant spectra of BSA adsorption between the two different developed polymers as seen in Figures $9 \mathrm{~b}$ and $11 \mathrm{~b}$ cannot be compared directly in a quantitative way as there are different conditions on the thickness or the surface properties of polymer layer that can alter significantly the strength of the resolved peaks. Also specific conditions during measurement such as various surface effects like partial delamination of the specific polymer film could also alter the derived spectrum. In Figure $11 \mathrm{~b}$ the two strong peaks attributed to BSA adsorption/binding are clearly identified. However the specific spectrum in Figure 11b after BSA was washed (green line) was derived only after the end of all the sets of measurements and repeatability tests where the overlayer (due to the relatively large thickness) was seriously degraded. The absence of remained BSA peaks (due to permanent covalent binding) is attributed to this specific degraded area, however the peak at $1655 \mathrm{~cm}^{-1}$ can still be noticed.

Further studies are in progress to improve the deposition quality of the layers and optimally tune the hydrophobicity of the anchoring PMMA block for improving the stability and adhesion quality of the overlayer as well as to optimize the hydrophilicity of the interacting blocks in order to enhance the operability on aqueous environment.

The irreversible covalent binding mechanism in this BCP could be employed for the development of single use detection heads operating as protein indicators, given also that the overall cost of the large core optical fiber head development is very low. A possibility also to use the two different reversible and irreversible sensing mechanisms in the same material is to design a self-referenced, ratio-metric approach based on the provision of reference level by the response attributed to the permanent binding at a specific suitably selected concentration. Another possibility that could be exploited is the use of covalent binding for the irreversible attachment of proteins towards the successive permanent immobilization of antibodies for selective sensing; while the reversible electrostatic-based adsorption mechanism will operate at the same time. This dual operation can provide some proteins discrimination functionality. 


\section{Conclusions and Future Work}

We have presented the design and synthesis of new amphiphilic block copolymers containing both hydrophobic and hydrophilic blocks for efficient protein detection. The combination of both blocks in the $\mathrm{PMMA}_{117}-b$-PDMAEMA 16 and the vinyl-sulfone functionalized $\mathrm{PMMA}_{117}-b-\mathrm{P}\left(\mathrm{DMAEMA}_{17}-\mathrm{VSTEMA}_{2}\right)$ amphiphilic block copolymer materials leads to the formation of robust overlayers on the fiber surface and efficient adsorption of the negatively charged BSA molecules. The synthesized copolymers have a well-defined structure as revealed from GPC.

A fiber optic based protein sensor functionalized with the copolymer materials was developed in order to assess the sensing performance of the copolymers. The deposition of the polymeric materials was performed using direct side polymer and dip coating techniques. When using direct side polymer deposition of the PMMA ${ }_{117}-b$-PDMAEMA ${ }_{16}$ and $\mathrm{PMMA}_{117}-b-\mathrm{P}\left(\mathrm{DMAEMA}_{17}-\mathrm{VSTEMA}_{2}\right)$ polymer, the layers produced were thick $(\sim 7 \mu \mathrm{m})$, resulting in a high detection limit (BSA concentrations ranging from $0.25 \%$ to $1 \% \mathrm{w} / \mathrm{v})$ and deformation of the film after excessive use. On the contrary, very thin $(\sim 30 \mathrm{~nm})$ and smooth overlayers of $\mathrm{PMMA}_{117}-b$-PDMAEMA 16 polymer were obtained with the dip coating technique leading to good and reversible response of the sensor, decreasing the detection limit by one order of magnitude (BSA concentration ranging from $0.025 \%$ to $0.1 \% \mathrm{w} / \mathrm{v}$ ). Extensive ATR-FTIR analysis was also performed, confirming the efficient protein adsorption according to polymers' design.

The sensing performance of the $\mathrm{PMMA}_{117}-b-\mathrm{P}\left(\mathrm{DMAEMA}_{17}-\mathrm{VSTEMA}_{2}\right)$ block polymer showed that an increase in polymer's hydrophobicity is probably needed in order to optimize overlayers' characteristics and reduce thus the degradation effects of the film after repeated immersions in protein solutions. One future direction of research would be the evaluation of effects related to block copolymer composition, phase separation within the layers and the number of vinyl sulfone groups within the copolymer chains on the selectivity and sensitivity of the active copolymer material. In future work selectivity enhancement will be studied by the immobilization on the polymer layer of antibodies or thiol-terminal DNA (aptamers). Additionally, various biomolecules will be studied, i.e. proteins containing different amounts of free thiols, disulfide and/or primary amine groups to assess their reactivity with the vinyl sulfone functionalized overlayer [35]. Materials optimization will lead also to improved sensitivity by employing them in photonic platforms with resonant optical components like Bragg gratings [17] in integrated optofluidic devices [36] for lab-on-chip applications.

\section{Acknowledgments}

We acknowledge support of this work by the project "Advanced Materials and Devices" (MIS 5002409) which is implemented under the "Action for the Strategic Development on the Research and Technological Sector", funded by the Operational Programme "Competitiveness, Entrepreneurship and Innovation" (NSRF 2014-2020) and co-financed by Greece and the European Union (European Regional Development Fund). The COST Action BM1401 "Raman-based Applications for Clinical Diagnostics (Raman4Clinics)" is also acknloweledged. 


\section{References}

[1] L. D. Li, Z. B. Chen, H. Zhao, L. Guo, X. Mu, An aptamer-based biosensor for the detection of lysozyme with gold nanoparticles amplification, Sens. Actuator B-Chem. 149 (2010) 110-115.

[2] J. O. Lee, H. M. So, E. K. Jeon, H. Chang, K. Won, Y. H. Kim, Aptamers as molecular recognition elements for electrical nanobiosensors, Anal. Bioanal. Chem. 390 (2008) 1023-1032.

[3] Z. Chen, L. Li, H. Zhao, L. Guo, X. Mu, Electrochemical impedance spectroscopy detection of lysozyme based on electrodeposited gold nanoparticles, Talanta 83 (2011) 1501-1506.

[4] C. Wang, D. Wang, G. Wang, X. Hu, Determination of lysozyme using microcantilever sensor based on atomic force microscopy, Chin. J. Anal. Chem. 38 (2010) 1771-1775.

[5] L. Bao, X. Qu, H. Chen, X. Su, S. Yao, W. Wei, A bulk acoustic wave viscosity sensor for determination of lysozyme based on lysis of Micrococcus lysodeikeicus, Mikrochim. Acta 132 (1999) 61-65.

[6] N. Cennamo, D. Massarotti, L. Conte, L. Zeni, Low cost sensors based on SPR in a plastic optical fiber for biosensor implementation, Sensors 11 (2011) 11752-11760.

[7] C. Caucheteur, T. Guo, J. Albert, Review of plasmonic fiber optic biochemical sensors: improving the limit of detection, Anal. Bioanal. Chem. 407 (2015) 3883-3897.

[8] T. Riedel, F. Surman, S. Hageneder, O. Pop-Georgievski, C. Noehammer, M. Hofner, E. Brynda, C. Rodriguez-Emmenegger, J. Dostálek, Hepatitis B plasmonic biosensor for the analysis of clinical serum samples, Biosens. Bioelectron. 85 (2016) 272-279.

[9] A. Petropoulou, M. N. Zervas, C. Riziotis, Design optimization of gold-coated fiber tips with embedded plasmonic slot nano-resonators, J. Opt. 19 (2017) 055002.

[10] A. Petropoulou, G. Antonopoulos, P. Bastock, C. Craig, G. Kakarantzas, D. W. Hewak, M. N. Zervas, C. Riziotis, Robust plasmonic tips fabricated by the tapering of composite hybrid silicate microfibers with metallic core, Proc. SPIE 10028 (2016) 100280N.

[11] T. X. Liu, L. Zhang, R.-P. Liang, J. D. Qiu, Highly selective detection of disulfenylated proteins through a dimedone-based fluorescent probe and application in cells, Sens. Actuator B-Chem. 238 (2017) 257-263.

[12] X. Yang, C. Gu, F. Qian, Y. Li, J. Z. Zhang, Anal. Chem. 2011, 83, 5888-5894.

[13] X. Fan, I. M. White, Optofluidic microsystems for chemical and biological analysis, Nat. Photon. 5 (2011) 591-597.

[14] T. Matsunaga, T. Hishiya, T. Takeuchi, Surface plasmon resonance sensor for lysozyme based on molecularly imprinted thin films, Anal. Chim. Acta 591 (2007) 63-67.

[15] H. Akasaka, T. Nagao, L. Kiyoto, S. Ohshio, H. Saitoh, Detection of lysozyme adsorption on titania using surface plasmon resonance on Au layer coated with thin titania film, J. Ceram. Soc. Jpn. 118 (2010) 587-590.

[16] W. Zhang, N. Ganesh, I. D. Block, B. T. Cunningham, High sensitivity photonic crystal biosensor incorporating nanorod structures for enhanced surface area, Sens. Actuator B-Chem. 131 (2008) 279-284.

[17] I. J. G. Sparrow, P. G. R. Smith, G. D. Emmerson, S. P. Watts, and C. Riziotis, Planar Bragg grating sensors-fabrication and applications: A review, Journal of Sensors, 2009 (2009) 607647.

[18] F. Vollmer, L. Yang, Label-free detection with high-Q microcavities: a review of biosensing mechanisms for integrated devices, Nanopohotonics 1 (2012) 267-291.

[19] G. C. Righini, S. Sori, Biosensing by WGM microspherical resonators, Sensors 16 (2016) 905.

[20] V. Pruneri, C. Riziotis, P. G. R. Smith, A. Vasilakos, Fiber and integrated waveguide-based optical sensors, Journal of Sensors (2009) 171748. 
[21] F. Poncin-Epaillard, T. Vrlinic, D. Debarnot, M. Mozetic, A. Coudreuse, G. Legeay, B. El Moualij, W. Zorzi, Surface treatment of polymeric materials controlling the adhesion of biomolecules, J. Funct. Biomater. 3 (2012) 528-543.

[22] T. G. Vladkova, Surface engineered polymeric biomaterials with improved biocontact properties, Intern. Jour. Polym. Scien. 2010 (2010) 296094.

[23] A. El Sachat, A. Meristoudi, S. Pispas, C. Riziotis, Assessment of block and random copolymer overlayers on polymer optical fibers toward protein detection through electrostatic interaction, J. Polym. Sci. Part B Polym. Phys. 53 (2015) 327-334.

[24] L. Athanasekos, A. El Sachat, S. Pispas, C. Riziotis, Amphiphilic diblock copolymer-based multiagent photonic sensing scheme, J. Polym. Sci. Part B Polym. Phys. 52 (2014) 46-54.

[25] Z. Zhao, Y. Duan, A low cost fiber-optic humidity sensor based on silica sol-gel film, Sens. Actuator B-Chem. 160 (2011) 1340-1345.

[26] P. V. Preejith, C. S. Lim, A. Kishen, M. S. John, A. Asundi, Total protein measurement using a fiber-optic evanescent wave-based biosensor, Biotechnol. Lett. 25 (2003) 105-110.

[27] A. El Sachat, A. Meristoudi, C. Markos, A. Sakellariou, A. Papadopoulos, S. Katsikas, and C. Riziotis, Characterization of industrial coolant fluids and ageing monitoring by wireless-enabled fiber optic based sensors, Sensors MDPI 17 (2017) 568.

[28] N. Hadjichristidis, S. Pispas, G. Floudas, Block copolymers: Synthetic strategies, physical properties, and applications, John Wiley \& Sons (2003).

[29] O. W. Webster, Living polymerization methods, Science 251 (1991) 887-893.

[30] J. Chiefari, Y. K. B. Chong, F. Ercole, J. Krstina, J. Jeffery, T. P. T. Le, R. T. A. Mayadunne, G. F. Meijs, C. L. Moad, G. Moad, E. Rizzardo, S. H. Thang, C. South, Living free-radical polymerization by reversible addition-fragmentation chain transfer: The RAFT process, Macromolecules 31 (1998) 5559-5562.

[31] G. Moad, E. Rizzardo, S. H. Thang, Living radical polymerization by the RAFT process - A second update, Aust. J. Chem. 62 (2009) 1402-1472.

[32] E. Themistou, G. Battaglia, S. P. Armes, Facile synthesis of thiol-functionalized amphiphilic polylactidemethacrylic diblock copolymers, Polym. Chem. 5 (2014) 1405-1417.

[33] P. Viswanathan, E. Themistou, K. Ngamkham, G. Reilly, S. P. Armes, G. Battaglia, Controlling surface topology and functionality of electrospun fibers on the nanoscale using amphiphilic block copolymers to direct mesenchymal progenitor cell adhesion, Biomacromolecules 16 (2015) 66-75.

[34] J. Rosselgong, S. P. Armes, W. Barton, D. Price, Synthesis of highly branched methacrylic copolymers: observation of near-ideal behavior using RAFT polymerization, Macromolecules 42 (2009) 5919-5924.

[35] J. Morales-Sanfrutos, J. Lopez-Jaramillo, M. Ortega-Munoz, A. Megia-Fernandez, F. PerezBalderas, F. Hernandez-Mateo, F. Santoyo-Gonzalez, Vinyl sulfone: a versatile function for simple bioconjugation and immobilization, Org. Biomol. Chem. 8 (2010) 667-675.

[36] K. Kalli, C. Riziotis, A. Posporis, C. Markos, C. Koutsides, S. Ambran, A. S. Webb, C. Holmes, J. C. Gates, J. K. Sahu, P. G.R. Smith, Flat fibre and femtosecond laser technology as a novel photonic integration platform for optofluidic based biosensing devices and lab-on-chip applications: Current results and future perspectives, Sens. Actuator B-Chem. 209 (2015) 1030-1040. 


\section{Development of amphiphilic block copolymers as silica optical fiber overlayers for BSA protein detection}

\section{Highlights}

- Synthesis of novel amphiphilic block copolymers using methacrylic monomers

- Formation of stable polymeric films on optical fibers due to the hydrophobic PMMA

- Sensing negatively charged proteins as adsorbed by the hydrophilic PDMAEMA block

- Demonstration of permanent binding by thiol-ene reaction with cysteine in proteins

- Detection of BSA protein of $0.025 \% \mathrm{w} / \mathrm{v}$ with good linearity and reversibility 
PMMA $_{117^{-b}-\mathrm{P}\left(\mathrm{DMAEMA}_{17} \text {-st-VSTEMA }\right.}$ )

Silica optical fiber

Block copolymer

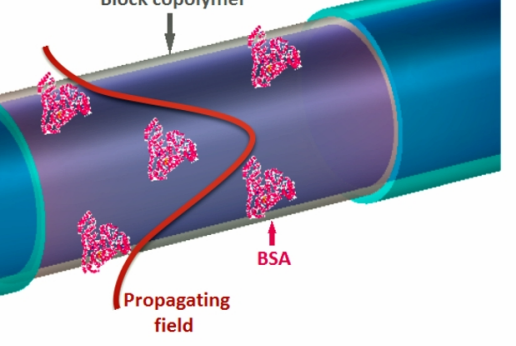

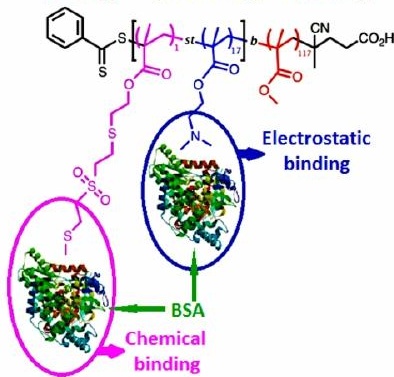

